Olgierd Kucharski (i) https://orcid.org/0000-0002-9633-9281

Uniwersytet Humanistyczno-Przyrodniczy im. Jana Długosza w Częstochowie

\author{
Paweł Wolnicki (1) https://orcid.org/0000-0002-2668-2018
}

Uniwersytet Humanistyczno-Przyrodniczy im. Jana Długosza w Częstochowie

\title{
PRAWO KOŚCIOŁÓW I INNYCH ZWIAZZKÓW WYZNANIOWYCH DO ŻAZDANIA OD KANDYDATA NA PRACOWNIKA DANYCH OSOBOWYCH O JEGO WYZNANIU LUB RELIGII
}

\begin{abstract}
The right churches and religious associationis to request information from an employee candidate about his confession and religion

In this work authors analyze existing legal regulations in the state legal order, concernig processing of personal data on employments in churches and religious associotions. Some of churches and religious associotions introduce regulations limiting access to employment in their structures for people professing different faith or views. They carry out their prophetic mission only or primarily with the participation of their own followers, opening themselves to all people, or only those who meet the requirements defined by internal law. This special legal relationship between an employee (candidate to empolyee) a church and other religion organizations as the employing entity, resulted from participation in the implementation of religious purposes, in especially the right of personal data about candidtae of employment proffesing.
\end{abstract}

Słowa kluczowe: kościoły i inne związki wyznaniowe, dane osobowe, prawo pracy

Keywords: churches and religious associations, personal data, labour law

ASJC: 3308, JEL: K31

\section{Wprowadzenie}

Wskutek rozwoju sposobów komunikowania się do istotnych problemów zaczęto zaliczać ochronę danych osobowych. Uznano, że jest to bardzo ważne dobro osobiste 
zasługujące na szczególne traktowanie i zabezpieczenie przed nieuprawnionym dostępem i przetwarzaniem. O ile ogólna zasada nie budzi kontrowersji, o tyle problemy pojawiają się w rozwiązaniach szczegółowych, w których trzeba dokonać wyboru, kiedy ochrona niektórych danych osobowych konkretnej osoby musi ustąpić w imię obrony innych ważnych dla społeczeństwa wartości.

W prawie pracy ustawodawca wprowadził regulacje, które szczegółowo określają, jakich danych od kandydata na pracownika może żądać pracodawca, uznając je za niezbędne do prawidłowego naboru. Chcielibyśmy w tej pracy przedstawić ważne i budzące spory zagadnienie, w jakich sytuacjach zatrudniające podmioty konfesyjne mają dostęp do danych o wyznaniu lub religii kandydata na pracownika.

\section{Zagadnienia ogólne}

W polskim obrocie prawnym grupy religijne mogą uzyskać osobowość prawną, funkcjonując pod własną formą organizacyjną, którą ustawodawca zdefiniował jako kościoły i inne związki wyznaniowe ${ }^{1}$. W doktrynie przyjęło się, że pojęcie „związki wyznaniowe" jest szersze i obejmuje wszystkie podmioty tego rodzaju, w tym także kościoły, jako niektóre ze wspólnot religijnych wchodzących w skład związków wyznaniowych (Osuchowski 1996, s. 24; Garlicki 2005, uwaga 8; Zieliński 2007, s. 46-51). Polski prawodawca w art. 2 ustawy o gwarancjach wolności sumienia i wyznania określa kościoły i inne związki wyznaniowe za pomocą definicji funkcjonalnej jako te, które są zakładane w celu wyznawania i szerzenia wiary religijnej. Wskazuje też ich podstawowe cechy, wymieniając: własny ustrój, doktrynę i obrzędy kultowe (art. 2 pkt 1 ustawy o gwarancjach wolności sumienia i wyznania; na cel religijny jako konieczną przesłankę uzyskania statusu kościołów i innych związków wyznaniowych wskazuje NSA w wyroku z 23 stycznia 1998 r., I SA 1065/97, ONSA 1998, z. 4, poz. 135). Kościoły i inne związki wyznaniowe stanowią zatem specyficzny typ zorganizowanej społeczności ludzkiej, która stawia sobie za cel zapewnienie realizacji potrzeb religijnych (Rynkowski 2004, s. 14 i n.; Pietrzak 2013, s. 13).

Wyjaśniając, dlaczego kościoły i inne związki wyznaniowe są traktowane w sposób uprzywilejowany w dostępie do informacji o wyznawanej wierze lub religii kandydata na pracownika, należy wskazać, że funkcjonowanie tych podmiotów konfesyjnych (w ramach konstrukcji prawnej: kościoły i inne związki wyznaniowe) jest gwarantem realizacji w wymiarze społecznym należnej każdemu człowiekowi wolności sumienia, wyznania i religii. Prawodawca zapewnia ją poprzez zagwarantowanie w najwyższej rangi

1 Ustawodawca krajowy nie odróżnia kościołów od związków wyznaniowych jako odrębnych podmiotów prawa, lecz niezależnie od przyjętej przez daną konfesję nazwy (kościół, zbór, stowarzyszenie, wspólnota, związek wyznaniowy, zrzeszenie) włącza je do tej samej jakościowej kategorii: kościołów i innych związków wyznaniowych. Wynika to z art. 2 ust. 1 ustawy z dn. 17 maja 1989 r. o gwarancjach wolności sumienia i wyznania, Dz.U. 2017, poz. 1153 tekst jedn., dalej: „ustawa o gwarancjach wolności sumienia i wyznania”. 
aktach prawnych - swobody wyznawania prywatnego i publicznego wiary, uprawiania kultu, modlitwy, obrzędów, nauczania i prawa do posiadania świątyń (art. 53 pkt 2 Konstytucja Rzeczypospolitej Polskiej z dn. 2 kwietnia 1997 r., Dz.U. 1997, nr 78, poz. 483 ze zm., dalej: „Konstytucja RP”, „Konstytucja”). Kościoły i inne związki wyznaniowe powinny mieć możliwość realizacji tych wolności w sposób umożliwiający swobodne wyznawanie i szerzenie wiary religijnej, zgodnie ze swoją doktryną i za pomocą różnych form kultu oraz tworząc dla spełnienia tych zadań własne struktury (art. 2 pkt 1 ustawy o gwarancjach wolności sumienia i wyznania; sfery te w Kościele katolickim określone zostały jako realizacja misji nauczania, uświęcania i pasterzowania, wskazania soborowe znalazły zaś swój wyraz w Kodeksie prawa kanonicznego, 32). W tym zakresie, w relacji do państwa, posiadają przymiot autonomii i niezależności, stanowiących podstawę bilateralnej zasady wzajemnych stosunków, co pozwala im na działalność zgodnie z własnymi założeniami i samoświadomością (art. 25 ust. 3 i art. 1 Konkordatu między Stolicą Apostolską i Rzecząpospolitą Polską, podpisanego w Warszawie dn. 28 lipca 1993 r., Dz.U. 1998, nr 51, poz. 318, dalej: „Konkordat”; Krukowski 1999, s. 68-72; Góralski, Pieńdyk 2000, s. 11-23; Krukowski 2000, s. 68-72). Dlatego państwo musi uznać ich prawo do spraw ze „swojego zakresu” (Zieliński 2011, s. 25). Ta autonomia sprawia, że podmioty konfesyjne posiadają prawo do samookreślenia się jako instytucje o charakterze religijnym (Orzeszyna 2007, s. 44). W tę sferę samoświadomości państwo ani jego organy nie powinni ingerować (Sobański 1999, s. 7-9). Oznacza to tė̇, że nabywają one wyłączne prawo do decydowania o swojej tożsamości², a więc o formach organizacji, sposobach realizacji celów, podejmowanych działaniach i zadaniach. Określają je i realizują według wewnętrznych unormowań, procedur, praktyk czy zwyczajów. Przy tym owa autonomia nie może mieć charakteru absolutnego, wykluczającego podporządkowanie się przepisom prawa obowiązującego („świeckiego”), przede wszystkim dotyczącego porządku publicznego (Garlicki 2010, s. 582; Borecki 2012, s. 92). Konieczność respektowania przepisów obowiązującego prawa nie jest w takim przypadku naruszeniem konstytucyjnej zasady niezależności, utożsamianej z brakiem podporządkowania podmiotom zewnętrznym (Banaszak 2012, s. 187).

Podsumowując, można stwierdzić, że aspekt religijny, profetyczna działalność i cele ukierunkowane na ich spełnienie, wraz z wywodzonym $\mathrm{z}$ danej religii katalogiem zasad etyczno-moralnych, preferowanych w danej konfesji, odróżniają kościoły i inne związki wyznaniowe od innych wspólnot politycznych, społecznych, kulturowych czy ekonomicznych, determinując ich specyfikę i cel oraz kompetencje w państwowym porządku prawnym między innymi jako podmiotów zatrudniających ${ }^{3}$.

2 Pojęcie tożsamość w znaczeniu etymologicznym oznacza pewien stopień samodzielności i autonomiczności. Istota tożsamości polega więc tu na tym, że podstawę do bycia samym sobą podmiot wywodzi wyłącznie z samego siebie (Gołembski 2005, s. 14-15).

3 Konstytucja... ([1965]), nr 42: „Właściwe posłannictwo, jakie Chrystus powierzył swojemu Kościołowi, nie ma charakteru politycznego, gospodarczego czy społecznego. Cel bowiem, jaki Chrystus nakreślił Kościołowi, ma charakter religijny. Ale z tejże właśnie religijnej misji wypływa zadanie, światło i siły, które mogą służyć założeniu i utwierdzeniu wspólnoty ludzkiej według prawa Bożego". 
Wskazana wyżej skrótowa charakterystyka podmiotów konfesyjnych (tworzonych przez kościoły i inne związki wyznaniowe) miała na celu uwypuklenie ich specyfiki, która mając oparcie w regulacjach prawnych, pozwala na ich odmienne - od innych pracodawców funkcjonujących w obrocie prawnym - traktowanie w niektórych wymiarach.

\section{Wyłączenie zasady dyskryminacji w podmiotach konfesyjnych w zakresie danych o religii i wyznaniu}

Polska Konstytucja w art. 32 stanowi zasadę równości wobec prawa. Wszyscy mają zatem prawo do równego traktowania przez władze publiczne. Równość taka nie oznacza jednak identyczności traktowania podmiotów znajdujących się w różnych sytuacjach, gdyż to prowadziłoby do egalitaryzmu prymitywnego (Wolnicki, Kucharski 2018, s. 72).

Dziedziną życia narażoną na praktyki dyskryminacyjne jest sfera zatrudnienia. Dyskusja wokół sposobów ograniczenia tego typu patologii została podjęta na forum międzynarodowym już na początku drugiej połowy XX w. Efektem tych działań była Konwencja Międzynarodowej Organizacji Pracy, dotycząca dyskryminacji w zakresie zatrudnienia i wykonywania zawodu (przyjęta w Genewie dn. 25 czerwca 1958 r., Dz.U. 1961, nr 42, poz. 218), która została przyjęta i ratyfikowana również przez Polskę. Dodatkowo na kształt przepisów krajowego prawa pracy ma wpływ przyjęta przez Radę Unii Europejskiej dyrektywa nr 2000/78/ WE z dn. 27 listopada 2000 r., ustanawiająca ogólne warunki ramowe równego traktowania w zatrudnieniu i płacy (Dz.Urz. UE L 2000, nr 303, LEX nr 32000L0078, dalej: „,dyrektywa z dn. 27 listopada 2000 r.”).

Wskazane akty prawne niewątpliwie stały się inspiracją do wprowadzania przepisów antydyskryminacyjnych w Kodeksie pracy (ustawa z dn. 26 czerwca 1974 r. - Kodeks pracy, Dz.U. 2018, poz. 917 tekst jedn. ze zm., dalej: „Kodeks pracy”, „k.p.”). Dostosowanie jego przepisów do unijnych dyrektyw nastąpiło mocą ustawy z dn. 14 listopada 2003 r. o zmianie ustawy Kodeks pracy oraz zmianie niektórych innych ustaw (Dz.U. 2003, $\mathrm{nr} 213$, poz. 2081). Ponadto $\mathrm{z}$ dn. 1 stycznia $2011 \mathrm{r}$. weszła w życie ustawa o wdrożeniu niektórych przepisów Unii Europejskiej w zakresie równego traktowania (Dz.U. 2010, nr 254, poz. 1700).

Podstawową regulację antydyskryminacyjną zawarto w art. $11^{3}$ k.p., który stanowi, że:

Jakakolwiek dyskryminacja w zatrudnieniu, bezpośrednia lub pośrednia, w szczególności ze względu na płeć, wiek, niepełnosprawność, rasę, religię, narodowość, przekonania polityczne, przynależność związkową, pochodzenie etniczne, wyznanie, orientację seksualną, a także ze względu na zatrudnienie na czas określony lub nieokreślony albo w pełnym, lub w niepełnym wymiarze czasu pracy - jest niedopuszczalna.

Szczegółowo zasady zakazujące dyskryminacji zostały rozwinięte w art. $18^{3 a}$ do art. $18^{3 e}$ k.p. W związku z tymi przepisami rodzi się pytanie: czy kierowanie się przynależnością religijną, przekonaniami o charakterze wyznaniowym i światopoglądowym w zatrudnieniu 
jest dopuszczalne w działalności kościołów i innych związków wyznaniowych pełniących rolę pracodawców? Chcąc odpowiedzieć na to pytanie, na wstępie należy zauważyć, że polska Konstytucja i prawo wspólnotowe, zakazując dyskryminacji z uwagi na kryterium religii, wyznania i światopoglądu, nie zakazują różnicowania sytuacji prawnej osób fizycznych i prawnych. Przesłanki dopuszczające różnicowanie sytuacji prawnej osoby ze względu na religię, wyznanie czy światopogląd znajdują swoje umocowanie w prawie unijnym i krajowym. W odniesieniu do zatrudniania pracowników znajdują się one w art. $18^{3 \mathrm{~b}} \$ 4$ k.p. oraz art. 24 dyrektywy z dn. 27 listopada 2000 r. (s. 80). Orzecznictwo ETPC również wypracowało przesłanki dopuszczające różnicowanie sytuacji prawnej osoby ze względu na religię, wyznanie czy światopogląd (Nowicki 2011, s. 188). Wskazana dyrektywa $\mathrm{z}$ dn. 27 listopada 2000 r. w art. 4 ust. 1 stanowi, że odmienne traktowanie ze względu na cechy związane z jedną z przyczyn nie stanowi dyskryminacji, wówczas gdy ze względu na rodzaj działalności zawodowej lub jej okoliczności dane cechy są istotnym i determinującym wymogiem zawodowym (Stanisz 2005, s. 48). Wymagane jest jednak spełnienie w tym przypadku jeszcze dwóch przesłanek: zgodności z prawem celu, ze względu na który postawione zostały te wymagania, oraz proporcjonalności tych wymagań do konkretnej sytuacji, na co wyraźnie wskazuje także art. $18^{3 \mathrm{~b}} \S 4$ k.p. (Stanisz 2005, s. 49), który jednak w odróżnieniu od tej dyrektywy mówi o rzeczywistym i decydującym wymogu zawodowym. Oba te pojęcia są jednak niedookreślone, a zatem na ich interpretację będą wpływały orzeczenia krajowych sądów w indywidualnych sprawach dotyczących dyskryminacji ze względu na religię i wyznanie.

Konieczność wskazania rzeczywistego i decydującego wymagania zawodowego stawianego pracownikom, proporcjonalnego do osiągnięcia zgodnego z prawem celu zróżnicowania sytuacji tej osoby, w przypadku kościołów i innych związków wyznaniowych będzie zdeterminowane ich etyką (Mik 2003, s. 153). Charakterystyczne i warte podkreślenia jest to, że wspólnym źródłem tej etyki jest nie tyle rozum i ludzkie doświadczenie, ile wiara religijna, a dla wielu grup także boże objawienie. Podmioty te bowiem opierają swoją tożsamość na autorytecie moralnym, mającym podstawy w wyznawanej religii i etyce, a pozbawienie kościołów i innych związków wyznaniowych możliwości oceny kandydata pod tym względem stałoby w sprzeczności z celem ich utworzenia i funkcjonowania (Stanisz 2005, s. 51). Zasada równego traktowania nie może zatem być rozumiana jako negacja opierającej się na religijnych wartościach istoty działalności tych podmiotów (Stanisz 2006, s. 509). Przesłanka zgodności z prawem celu, ze względu na który zostały postawione te wymagania osobom zatrudnianym, opiera się bowiem na zadaniach (profetycznej misji etyczno-moralnej, zakorzenionej w religii) ustalanych autonomicznie przez dany kościół lub inny związek wyznaniowy w ich prawie wewnętrznym (kanonicznym).

Wymaga podkreślenia, że działalność kościołów i innych związków wyznaniowych oraz ich jednostek organizacyjnych jest podporządkowana profetycznemu celowi, często transcendentnemu, polegającemu na wyznawania i szerzeniu wiary religijnej. Chroniąc te wartości i umożliwiając realizację wolności religijnej w wymiarze wspólnotowym, polska Konstytucja wprowadziła do krajowego porządku konstrukcję prawną kościołów 
i innych związków wyznaniowych, odróżniając je od innych organizacji, stowarzyszeń, ruchów czy zrzeszeń.

Działania poszczególnych reprezentantów osób prawnych, kościołów i innych związków wyznaniowych, nawet niezwiązane z celem podstawowym, realizują jednak cele częściowe, które zawsze są w tych wspólnotach podporządkowane zadaniu podstawowemu (wyznawania i szerzenia wiary religijnej oraz etyki i moralności), rozumianemu jako jego profetyczna misja, i nie mogą być rozpatrywane w oderwaniu od niego. Oznacza to, że to cel podstawowy wyróżnia daną wspólnotę konfesyjną i precyzuje bądź odzwierciedla jej tożsamość. Czyni on zatem zadość wymaganiom dyrektywy z dn. 27 listopada 2000 r., wskazującej na przesłankę zgodnego z prawem celu różnicowania sytuacji osoby zatrudnionej (Stanisz 2005, s. 49). Ponadto wyrażone w art. $18^{\mathrm{b}} \$ 4$ k.p. kryterium religii, wyznania i światopoglądu należy rozumieć w kontekście doktrynalnym (Mielczarek 2013, s. 127). Jest on bowiem związany z religijną i profetyczną misją wspólnot konfesyjnych (Seifert 2009, s. 556-557). Stąd - zgodnie z art. 25 ust. 3 Konstytucji RP, a w odniesieniu do Kościoła katolickiego także art. 1 Konkordatu - to dany kościół lub inny związek wyznaniowy w sposób autonomiczny stanowią o swojej tożsamości i jej wyrazach. Jak zauważa Europejski Trybunał Praw Człowieka, „dawanie świadectwa słowami i czynami jest związane z istnieniem przekonań religijnych, jako że uzewnętrznianie przez jedną osobę jej przekonań religijnych może wpływać na innych ludzi” (wyrok ETPC z 15 stycznia 2013 r., Eweida i in. [Ladele] p. Wielka Brytania, LEX nr 1252935).

Zasadne wydaje się twierdzenie, że decyzję o zatrudnianiu należy pozostawić autonomii kościoła lub innego związku wyznaniowego, które mają prawo do autodeterminacji, co potwierdza na przykład stanowisko niemieckiego Trybunału Konstytucyjnego (Kłączyńska 2005, s. 157). Jest ona bowiem określana autoświadomością danej religii, wyznania, światopoglądu, a nierzadko ich stosunkiem do transcendencji, także we wskazywaniu odrębności, dotyczących obowiązków osób zatrudnionych w podmiocie konfesyjnym, sposobem ich wykonania czy koniecznych kwalifikacji etyczno-moralnych. Przemawia za tym fakt, że osoba zatrudniona powinna identyfikować się z podstawowym celem tożsamościowym wspólnoty religijnej, na rzecz której świadczy pracę. To z kolei pozwala realizować w sposób świadomy założone przez kościoły i inne związki wyznaniowe cele $\mathrm{w}$ wymiarze nie tylko społecznym, ale też transcendentnym, jak to ma miejsce w przypadku chrześcijaństwa (Mt 18, 20: „Bo gdzie są dwaj albo trzej zebrani w imię moje, tam jestem pośród nich", za: BT, wyd. 4). Rola identyfikacji celów podmiotu zatrudniającego przez osobę zatrudnioną oraz przebywanie w przestrzeni o dużym nasyceniu osób, miejsc i przedmiotów, którym w danej religii należy okazywać bezpośrednio lub pośrednio kult, bądź napotykanie znacznej ilości symboliki sakralnej, cieszącej się wśród wyznawców szacunkiem, trudno nie uznać za rzeczywiste i decydujące wymagania zawodowe. Można stawiać pytanie o to, czy bezwyznaniowa osoba sprzątająca w kuchni klasztornej daje rękojmię należytego obchodzenia się przykładowo z wodą święconą, która jest w kropielnicy przed wejściem do refektarza, albo czy zatrudnienie takiej osoby na innym stanowisku pozwoli zabezpieczyć transcendentne wartości kościoła i innego związku wyznaniowego, do których dana osoba nie ma przekonania, a którym podporządkowane powinny być 
w tych wspólnotach wszystkie inne obszary. Należy się więc zgodzić ze stanowiskiem Andrzeja Mariana Świątkowskiego, że wyłączenie od zasady niedyskryminacji ze względu na religię, wyznanie, światopogląd należałoby stosować wobec „wszystkich osób fizycznych zatrudnianych w kościołach i innych związkach wyznaniowych bez względu na podstawę prawną i charakter prawny zatrudnienia" (Świątkowski 2016, komentarz do art. 18b $\$ 4$ k.p.). Z kolei na podstawie art. $18^{\mathrm{b}} \$ 4$ k.p. należy wnioskować, że warunek proporcjonalności wymagań zawodowych odnosi się do konkretnej sytuacji, w jakiej znalazł się podmiot zatrudniający, i z takiej perspektywy powinien też być rozpatrywany. Przy tym krajowy ustawodawca, wbrew przepisom dyrektywy z dn. 27 listopada 2000 r., nie sprecyzował pojęcia „wymagania zawodowe” jako przesłanki relatywizującej zasadę równego traktowania (Stanisz 2006, s. 34). Dlatego za zbyt ogólną należy uznać spotykaną w literaturze interpretację tego przepisu, sugerującą, że owo wymaganie zawodowe powinno być związane bezpośrednio z aktywnością religijną bądź wyznaniową, a więc przykładowo odnosić się do wykonywania przez osoby zatrudnione czynności o charakterze kultowym (Wagner [red.] 2004, s. 89; Ciborowski 2010, s. 26; Mielczarek 2013, s. 126; Świątkowski 2016, s. 83). Wydaje się, że powtarzanie tego stanowiska, choć jest w pełni uzasadnione, ma charakter redukcjonistyczny. Zawsze bowiem zatrudnienie na jakimś stanowisku w podmiocie konfesyjnym wpływa na jego wiarygodność. Należy przywołać tu również stanowisko Jaluba Ciborowskiego, który przedstawił pogląd, że kryterium religii lub wyznania powinno mieć konieczny i słuszny charakter, a w szczególności musi być nieodzowne dla zachowania ideologicznej tożsamości placówki zatrudniającej (Ciborowski 2010, s. 24). Dodatkowo autor ten precyzuje, że można odmówić zatrudnienia osoby, która mogłaby utrudniać realizację celów statutowych albo źle wpływać na atmosferę pracy - jego zdaniem raczej nie będzie to jednak dotyczyło pracowników technicznych (Ciborowski 2010).

Przedstawione wyżej rozważania miały na celu wyeksponowanie specyfiki podmiotów konfesyjnych. Jednak w naszym przekonaniu zatrudnienie w kościołach, innych związkach wyznaniowych bądź w ich jednostkach organizacyjnych nie może oznaczać tzw. klerykalizacji. Podporządkowanie w ramach umowy o pracę oznacza konieczność wykonywania poleceń zgodnych z zawartą umową o pracę oraz prawem, natomiast nie może wkraczać w pozostałe sfery życia pracownika. Muszą zostać zachowane proporcje wynikające z wolności jednostki. Polski ustawodawca ustanowił bowiem przesłanki dopuszczalnego różnicowania sytuacji pracowniczej jako wyjątki od zakazu nierównego traktowania, które stanowią katalog ścisłego traktowania i rozumienia w myśl zasady exceptiones non sunt extendendae (Lewandowski 2014, s. 143).

Podkreślenia wymaga fakt, że zasada niedyskryminacji i równego traktowania musi mieć zastosowanie w kościołach i innych związkach wyznaniowych. Za jej przestrzeganiem przemawiają etyczno-moralne zasady tych podmiotów konfesyjnych, oparte najczęściej na przyrodzonej godności każdego człowieka. Odstępstwa od tej zasady, które powinny mieć szczególnie uzasadniony charakter, powinny zależeć od decyzji opartej na prawnej autonomii i niezależności wspólnoty konfesyjnej w zakresie wewnętrznej organizacji i profetycznej misji religijno-moralnej. Dotyczy to w szczególności ograniczania przez 
kościoły i inne związki wyznaniowe dostępu do zatrudnienia ze względu na religię, wyznanie lub światopogląd, w przypadkach gdy rodzaj lub charakter wykonywanej przez pracownika działalności stanowi rzeczywiste i decydujące wymaganie zawodowe stawiane zatrudnionemu, proporcjonalne do osiągnięcia zgodnego $\mathrm{z}$ prawem celu zróżnicowania sytuacji tej osoby. Aktualne orzecznictwo Europejskiego Trybunału Sprawiedliwości podkreśla konieczność spełniania tych przesłanek w każdym badanym przypadku (wyrok TSUE z 17 kwietnia 2018 r., Vera Egenberger p. Evangelisches Werk für Diakonie und Entwicklung eV, C-414/16, LEX nr 2476520). W literaturze przedmiotu słusznie więc wskazuje się, że warunki te odnoszą się przede wszystkim do osób zatrudnianych w zawodach związanych $\mathrm{z}$ aktywnością kultową w podmiotach konfesyjnych, choć w świetle niniejszych wywodów dotyczą także sfery zatrudniania niezwiązanej bezpośrednio z kultem. Różnicowanie zatrudniania przez kościoły i inne związki wyznaniowe ze względu na religię stanowi wyraz troski o zachowanie tożsamości i szerzenie profetycznej misji religijno-moralnej przez podmiot konfesyjny korzystający z prawnej autonomii i niezależności ad intra. Z kolei państwo neutralne światopoglądowo nie powinno wkraczać w autonomiczną sferę wewnętrznej organizacji podmiotów konfesyjnych dotyczącą zatrudniania.

Przedstawione wyżej wywody wskazują, że z jednej strony autonomia kościołów i innych związków wyznaniowych jest niekwestionowana, ale jednocześnie pozostaje ona pod pełną jurysdykcją sądów powszechnych sprawdzających, czy nie dochodzi do przypadków dyskryminacji w zatrudnieniu (Matusiak-Frączak 2018). Oczywiste jest również, że każdy przypadek będzie indywidualnie rozstrzygany. Wydaje się jednak, że jest konieczne wskazanie pewnych rozwiązań jurydycznych, które pozwolą na rozwinięcie teoretycznej argumentacji przydatnej do rozwiązywania przyszłych sporów.

Regulacją, która zdaniem autorów pozwala na rozstrzyganie tych delikatnych problemów, jest art. $18^{3 \mathrm{~b}} \S 4 \mathrm{k}$.p. Jego treść określa sytuacje, kiedy kościoły i inne związki wyznaniowe mogą podejmować decyzje o dostępie do zatrudnienia (nawiązaniu stosunku pracy albo odmówienia zatrudnienia konkretnej osoby). $Z$ tego przepisu wynika, że takie prawo im przysługuje, gdy rodzaj lub charakter wykonywanej działalności powoduje, że „religia, wyznanie lub światopogląd są rzeczywistymi i decydującymi wymaganiami zawodowymi, stawianymi pracownikowi, proporcjonalnymi do osiągnięcia zgodnego z prawem celu". Ta część przepisu jest dosyć klarowna i została rozwinięta w literaturze. Określenie, czym jest „rzeczywisty i decydujący wymóg zawodowy”, daje się zidentyfikować na podstawie reguł starannego wykonywania danego zawodu, a przez to nawiązuje do normy art. 100 k.p.

Jednak nie każda sytuacja może być rozstrzygnięta przez tak proste rozwiązanie. Wcześniejsze rozważania wskazują, że kościoły oraz inne związki wyznaniowe, realizując swoją misję, w granicach swojej autonomii mogą również wprowadzać dodatkowe wymagania, niezrozumiałe dla osób niewierzących (np. kwestia dostępu do relikwii lub „święconej wody" - dla ateisty desygnaty tych pojęć nie są same w sobie czymś obiektywnie istniejącym). Dlatego konieczne jest uwzględnienie samodzielności w kreowaniu swojej wewnętrznej sytuacji przez kościoły i inne związki wyznaniowe, co jest zagwarantowane 
przez wskazane wyżej przepisy. Połączenie tych dwóch porządków: obiektywnego i ,autonomicznego" musi znaleźć swoje prawne unormowanie umożliwiające społecznie akceptowalne rozstrzygnięcie każdego sporu. Kluczowym uregulowaniem pozwalającym na rozumienie prawa kościołów i innych związków wyznaniowych do nawiązywania lub nie zatrudnienia $\mathrm{z}$ konkretnymi osobami, uwzględniającym jego autonomię do określania celów i swojej misji profetycznej, zawarto w drugiej części art. $18^{3 \mathrm{~b}} \$ 4$ k.p., gdzie określono, że „dotyczy to również wymagania od zatrudnionego działania w dobrej wierze i lojalności wobec etyki kościoła”. Pojęcia dobrej wiary i lojalności pozwalają na odesłanie do systemów wartości kierujących danym podmiotem konfesyjnym, opierając się na jego „autonomii” (która oczywiście powinna być zobiektywizowana w jego regułach wewnętrznych). Każda indywidualna sytuacja będzie musiała być rozstrzygana również z wykorzystaniem kategorii porządku wewnętrznego, która dla osoby niewierzącej nie ma obiektywnej wartości, ale dla danego kościoła posiada istotne znaczenie. Pominięcie tej sfery działalności kościołów i innych związków wyznaniowych mogłoby prowadzić do naruszenia ich gwarantowanych konstytucyjnie praw do autonomii. Bez regulacji prawnej pozwalającej na pogłębioną ocenę każdej sytuacji można sobie wyobrazić sytuację, w której muzyk wykonujący na co dzień muzykę należącą do nurtu „satanistycznego” wygrywałby procesy sądowe o dyskryminację, gdy jakiś kościół nie chciałby go zatrudnić w charakterze organisty.

Pojawia się zatem pytanie, czy kościoły i inne związki wyznaniowe mają niczym nieograniczone prawo do określania, kogo przyjmą do pracy. Odpowiedź na tak postawione pytanie jest oczywiście w świetle przedstawionych rozważań negatywna. Uwzględniając szeroką autonomię kościołów i innych związków wyznaniowych do kształtowania swojej sytuacji wewnętrznej, należy wskazać, że ta autonomia nie jest nieograniczona.

Wydaje się, że pewne znaczenie dla zrozumienia tej sytuacji może mieć podział pracowników kościołów lub związków wyznaniowych na wykonujących tzw. zawody wyznaniowe sensu stricto i zawody wyznaniowe sensu largo (Wolnicki, Kucharski 2018, s. 111). Niezależnie od formy zatrudnienia świadczenie pracy w kościołach i innych związkach wyznaniowych może nieraz wymagać specjalistycznego wykształcenia oraz doświadczenia zawodowego. W podmiotach tych istnieją bowiem pewne specyficzne zawody, które można by nazwać „zawodami wyznaniowymi”. W ujęciu wąskim (sensu stricto) taki charakter będą miały takie profesje jak: kościelny czy kościelna, nazywani niekiedy zakrystianami, organista czy kantor (Statut... 2009, pkt II.3). Te zawody są ściśle związane z aktywnością religijną i łączą się z realizacją czynności odnoszących się do spełniania kultu religijnego. De facto nie spotyka się więc ich w innych instytucjach publicznych lub prywatnych. Do grupy zawodów wyznaniowych sensu largo należą natomiast zawody występujące także $w$ innych podmiotach powołanych do realizacji określonych celów, a więc przykładowo: grabarze, kierownicy chórów, pracujące na plebaniach pomoce domowe (nazywane gospodyniami), pracownicy biurowi (w tym księgowi), pracownicy gospodarczy, dozorcy (stróże), sprzątaczki, administratorzy nieruchomości, informatycy czy administratorzy stron internetowych (Synod... 2008; Posiedzenie... 2010; Komisja ds. Świeckich Pracowników Kościelnych Archidiecezji 
Poznańskiej pkt 8; Prawo Zborowe Kościoła Adwentystów Dnia Siódmego, rozdz. 8, pkt 3). A zatem w przypadku organisty czy „kościelnego” możliwość kościoła lub innego związku wyznaniowego do ograniczenia dostępu do zatrudnienia tylko do osób określonego wyznania będzie wynikała z rzeczywistych i decydujących wymagań zawodowych, a także z konieczności zachowania przez pracownika dobrej woli i lojalności wobec etyki kościoła (dotyczyć to będzie również każdej osoby, która styka się w ramach swojego zakresu obowiązków z przedmiotami liturgicznymi).

W odniesieniu do prac, gdzie nie można tak jednoznacznie wskazać takich powodów (pracownicy wyznaniowi sensu largo), a jednocześnie ważnych dla zapewnienia pozytywnego odbioru obrazu kościoła lub związku wyznaniowego, zgodnego z jego profetyczną misją, podejmując decyzję o zatrudnieniu, można kierować się wymogiem działania w dobrej wierze i lojalnością wobec etyki wspólnoty konfesyjnej. W tym ostatnim zatem przypadku odrzucone zostaną kandydatury osób (nawet na stanowiska pomocnicze lub inne niezwiązane bezpośrednio z czynnościami liturgicznymi czy misją profetyczną), których styl życia, zachowanie głoszone poglądy stoją w sprzeczności z zasadami etyki kościoła lub innego związku wyznaniowego. Te wymogi będą miały oczywiście kluczowe znaczenie również w odniesieniu do pracowników wyznaniowych sensu stricto.

Wydaje się zatem, że tylko pewne kategorie prac czy stanowisk zajmowanych przez pracowników wyznaniowych sensu largo będą wyłączone spod działania art. 18 $8^{3 \mathrm{~b}}$ $\S 4$ k.p., gdzie wyznawana wiara lub religia nie będą miały znaczenia przy nawiązywaniu stosunku pracy.

\section{Dane osobowe dotyczące wyznania lub religii}

Przedstawione wyżej analizy mają pomóc w odpowiedzi na pytanie (kontrowersje w doktrynie prawa pracy), czy można żądać od kandydata do zatrudnienia oraz od pracownika danych dotyczących jego wyznania, religii lub światopoglądu. Zgodnie $\mathrm{z}$ art. $22^{1} \mathrm{k}$.p. informacje dotyczące wyznania czy religii konkretnego pracownika są uznawane za dane wrażliwe i pracodawca nie powinien ich gromadzić ani przetwarzać. Unormowanie tego przepisu jest pochodną definicji dyskryminacji w zatrudnieniu określonej $\mathrm{w}$ art. $18^{3 \mathrm{a}} \mathrm{k}$.p., który wskazuje, że żaden pracownik nie powinien być dyskryminowany ze względu na wyznawaną religię, wyznanie itp. Ustawodawca uznał, że najlepiej gdy pracodawca w ogóle tego rodzaju danych nie posiada, bo to zapobiega nierównemu traktowaniu z tej przyczyny. W tym zakresie pracownik posiada prawo do milczenia, co pozwala mu chronić jego prywatność (Mielczarek 2013, s. 106). Jednak takie jednoznaczne (bezwyjątkowe) stanowisko uniemożliwiałoby funkcjonowanie kościołów i innych związków wyznaniowych, a także realizowanie ich prawa do autonomii w zatrudnianiu, o czym pisano wyżej. Dodatkowo należy przypomnieć, że zgodnie $\mathrm{z}$ art. $18^{3 \mathrm{~b}} \$ 4$ k.p. podmioty konfesyjne mogą zatrudniać w niektórych przypadkach osoby, które są określonego wyznania. Pojawia się zatem problem sprzeczności dwóch 
regulacji Kodeksu pracy: jednej zakazującej gromadzenia danych o wyznaniu i drugiej umożliwiającej pracodawcy posiadanie takich danych.

Analiza warstwy językowej tych regulacji nie daje jednoznacznego rozwiązania. W art. $22^{1} \S 4$ k.p. wskazano, że pracodawca ma prawo żądania innych danych niż określone $\mathrm{w}$ tym przepisie, gdy taki obowiązek wynika $\mathrm{z}$ odrębnych przepisów. Tymczasem art. $18^{3 \mathrm{~b}} \S 4$ k.p. wskazuje na prawo pracodawcy do żądania tej informacji od pracownika, a nie na obowiązek. W dodatku to prawo pracodawcy nie dotyczy wszystkich osób zatrudnionych w kościołach i innych związkach wyznaniowych, a jedynie takich sytuacji gdy zgodnie ze wskazanym przepisem wykonywanie danej działalności powoduje, że:

[...] religia, wyznanie lub światopogląd są rzeczywistym i decydującym wymaganiem zawodowym stawianym pracownikowi, proporcjonalnym do osiągnięcia zgodnego z prawem celu zróżnicowania sytuacji tej osoby; dotyczy to również wymagania od zatrudnionego działania w dobrej wierze i lojalności wobec etyki kościoła, innego związku wyznaniowego.

Taka treść regulacji nie daje zatem z góry jednoznacznej odpowiedzi na pytanie, czy pracodawca może wymagać od pracownika danych o wyznaniu czy religii. Dodatkowo należy wskazać, że normy prawa Unii Europejskiej, a zwłaszcza Rozporządzenia Parlamentu Europejskiego i Rady UE z dn. 27 kwietnia 2016 r. w sprawie ochrony osób fizycznych w związku z przetwarzaniem danych osobowych i w sprawie swobodnego przepływu takich danych oraz uchylenia dyrektywy 95/46/ WE (Dz.Urz. UE L 2016, nr 119, LEX nr 32016R0679) szczególnie chronią osoby fizyczne przed jakimikolwiek nadużyciami. Będzie to dotyczyło zwłaszcza ochrony danych o religii i wyznaniu jako danych wrażliwych.

W świetle przepisów Kodeksu pracy i opinii judykatury kościół lub inny związek wyznaniowy mogą żądać od kandydata na pracownika lub od pracownika informacji o wyznawanej religii po spełnieniu warunku określonego w art. $18^{3 \mathrm{~b}} \S 4$ k.p., a zatem gdy wyznanie (religia) pracownika będzie rzeczywistym i decydującym wymaganiem zawodowym, proporcjonalnym do osiągnięcia zgodnego z prawem celu zróżnicowania sytuacji tej osoby (Mielczarek 2013, s. 121 i n.; Rączka 2014, s. 88; Sobczyk 2015, s. 74; Strzała 2015, s. 110).

W naszym przekonaniu dotyczy to „zawodów wyznaniowych” nie tylko sensu stricto, ale także w uzasadnionych wypadkach sensu largo (opisanych wyżej). W literaturze przedmiotu wskazano przykłady takich sytuacji - na przykład sprawowanie funkcji kościelnego, który poza opieką nad obiektami sakralnymi wykonuje czynności o charakterze liturgicznym (Mielczarek 2013, s. 128; Strzała 2015, s. 108), redaktora czasopisma religijnego, który musi dokonywać kwalifikacji treści, a więc obligatoryjnie wykazywać się znajomością doktryny danej wiary, organisty (pełniącego funkcje liturgiczne; Mielczarek 2013, s. 128), nauczyciela w szkole prowadzonej przez związek wyznaniowy (ponieważ rodzic kierujący dziecko do szkoły prowadzonej przez związek wyznaniowy ma prawo oczekiwać, że głoszone tam treści będą zgodne z doktryną tego związku wyznaniowego, a więc nauka będzie realizowana przez nauczyciela znającego i akceptującego te treści; 
Mielczarek 2013, s. 127). W tych wszystkich przypadkach oczywiste jest, że posiadanie określonego wyznania przez kandydata czy pracownika było rzeczywistym wymogiem zawodowym, natomiast brak akceptacji dla światopoglądu religijnego pracodawcy konfesyjnego przez daną osobę jest równoznaczny z samowykluczeniem się z grona potencjalnych zatrudnionych (Mielczarek 2013, s. 126). We wszystkich przypadkach, gdy pracownik w zakresie swoich obowiązków będzie reprezentował kościół lub inny związek wyznaniowy albo z racji wykonywanych czynności będzie z nim utożsamiany, musi liczyć się ze zobowiązaniem do życia w zgodzie z zasadami doktryny wiary tego związku. Chodzi o wyeliminowanie choćby cienia podejrzenia o cynizm czy hipokryzję w sposobie życia, na przykład gdy styl egzystencji pracownika odbiega od oficjalnie głoszonych przez instytucję zatrudniającą zasad. Wydaje się, że tak szerokie rozumienie analizowanych przepisów jest konieczne, aby chronić kościoły i inne związki wyznaniowe przed nadużyciami, dokonywanymi w imię politycznej poprawności. Przede wszystkim jest to jednak istotne dla ochrony tożsamości religijnej, wyznaniowej czy światopoglądowej tych podmiotów konfesyjnych oraz celu ich powołania i funkcjonowania. Dlatego w opisywanym zakresie prawo pracownika do prywatności, w naszym przekonaniu, ulega ograniczeniu. Uzasadnienie tego wyjątku znajdziemy w art. 53 Konstytucji, określającym prawo każdego człowieka do wolności sumienia i religii. Brak zagwarantowania swobody w wyznawaniu religii, w szczególności brak gwarancji autonomii kościołów i związków wyznaniowych, faktycznie uniemożliwiałby ich funkcjonowanie. W przypadkach opisanych wyżej podmioty konfesyjne mają zatem prawo do żądania informacji od kandydata na pracownika o jego wyznaniu lub religii, by móc zatrudniać tylko osoby o określonych przekonaniach, a w konsekwencji zachować swoją tożsamość. Brak takiej możliwości oznaczałby, że podmioty konfesyjne nie mogłyby faktycznie realizować swojej misji. Indywidualne prawo pracownika do prywatności nie jest absolutne i musi ulec ograniczeniu, gdy godzi w dobro o dużo wyższej wartości, a takim jest niewątpliwie wolność sumienia i wyznania. Interpretacyjne wątpliwości związane z treścią art. $22^{1}$ k.p. i możliwością żądania w wyjątkowych przypadkach danych o wyznaniu lub religii powinny ustąpić wobec normy konstytucyjnej, ponieważ odmienne stanowisko doprowadziłoby faktycznie do uchylenia gwarancji zawartej w art. 53 Konstytucji, co w naszym przekonaniu jest niedopuszczalne.

\section{Podsumowanie}

Przeprowadzona analiza miała na celu wykazanie, że kościoły i związki wyznaniowe dysponują znaczną swobodą w zakresie określania stanowisk, do zajmowania których wymagane jest posiadanie określonego wyznania. Niestety, nie jest możliwe stworzenie wykazu zawodów, których wykonywanie uprawniałoby kościoły i związki wyznaniowe do żądania od kandydata do zatrudnienia takiej informacji, co - mamy nadzieję - zostało wykazane wyżej. Problemem, jaki w związku z tym się pojawia, jest to, że ustawodawca nie wskazał w art. $22^{1}$ k.p. w katalogu danych osobowych, których można żądać od 
kandydata na pracownika, informacji o jego wyznaniu lub religii. Bez takiej jednak wiedzy podmioty konfesyjne nie będą w stanie realizować swojej misji gwarantowanej konstytucyjnie. Dodatkowo, co również uzasadniono, przepisy zapobiegające dyskryminacji w zatrudnieniu pozwalają opisywanym podmiotom na faktyczne posiadanie takiej wiedzy. W naszym przekonaniu, pomimo braku jednoznacznego unormowania ustawowego, podmioty konfesyjne, prowadząc procedury naboru na stanowisko, gdzie wyznanie lub religia kandydata mają istotne znaczenie, mogą żądać takiej informacji.

\section{Bibliografia}

Banaszak B. (2012) Konstytucja Rzeczypospolitej Polskiej. Komentarz, Warszawa.

Borecki P. (2012) Autonomia kościołów i innych związków wyznaniowych we wspótczesnym prawie polskim, „Studia z Prawa Wyznaniowego", t. 15.

Ciborowski J. (2010) Kontratyp od zasady równego traktowania $w$ zatrudnieniu w podmiotach o charakterze wyznaniowym, „Praca i Zabezpieczenie Społeczne”, nr 4.

Garlicki L. (2005) [w:] L. Garlicki (red.), Konstytucja Rzeczypospolitej Polskiej. Komentarz, t. 5, Warszawa.

Garlicki L. (red.) (2010) Konwencja o Ochronie Praw Człowieka i Podstawowych Wolności. Komentarz do art. 1-18, t. 1, Warszawa.

Gołembski F. (2005) Tożsamość europejska (aspekty teoretyczne) [w:] F. Gołembski (red.), Tożsamość europejska, Warszawa.

Góralski W., Pieńdyk A. (2000) Zasada niezależności i autonomii Państwa i Kościoła w konkordacie polskim z 1993 roku, Warszawa.

Kłączyńska N. (2005) Dyskryminacja religijna a prawnokarna ochrona wolności sumienia i wyznania, Wrocław.

Konstytucja duszpasterska o kościele w świecie wspótczesnym „Gaudium et Spes” ([1965]) [w:] Sobór Watykański II. Konstytucje, dekrety, deklaracje, Poznań.

Krukowski J. (1999) Konkordat polski - znaczenie i realizacja, Lublin.

Krukowski J. (2000) Kościół i Państwo. Podstawy relacji prawnych, Lublin.

Lewandowski M. (2014) Ochrona pracownika przed dyskryminacja w polskim prawie pracy, „Palestra”, nr 3-4.

Matusiak-Frączak M. (2018) Zatrudnianie przez wspólnoty wyznaniowe lub organizacje religijne a zasada niedyskryminacji ze względu na religię lub przekonania - glosa do wyroku Trybunatu Sprawiedliwości z dnia 17 kwietnia 2018 r. w sprawie C-414/16 Egenberger, LEX nr 2476520.

Mielczarek M.A. (2013) Realizacja wolności religijnej w zatrudnieniu pracowniczym, Warszawa. Mik C. (2003) Czynniki religijny i etyczny w prawie i praktyce Unii Europejskiej [w:] J. Krukowski, O. Theisen (red.), Materialy III Międzynarodowej Konferencji na temat „Religia i wolność religijna w Unii Europejskiej", Warszawa 2-4 września 2002, Lublin.

Nowicki M.A. (2011) Europejski Trybunał Praw Człowieka. Wybór orzeczeń 2010, Warszawa.

Orzeszyna K. (2007) Podstawy relacji między państwem a kościołami w konstytucjach państw członkowskich i traktatach Unii Europejskiej: studium prawnoporównawcze, Lublin. 
Osuchowski J. (1996) Stosunki wyznaniowe w Polsce na tle transformacji ustrojowej, Warszawa. Pietrzak M. (2013) Prawo wyznaniowe, Warszawa.

Posiedzenie Rady S[K]IKEA, 16.09.2010 (2010) http://bik.luteranie.pl/pl/aktualnosci125.html (dostęp: 16.07.2016).

Rączka K. (2014) [w:] M. Gersdorf, M. Raczkowski M., Kodeks pracy. Komentarz, Warszawa. Rynkowski M. (2004) Status prawny kościołów i związków wyznaniowych w Unii Europejskiej, Warszawa.

Seifert A. (2009) Religious in the Workplace. The Case of the Federal Republic of Germany, „Comparative Labor Law. Policy Journal”, nr 3.

Sobański R. (1999) Prawo kanoniczne a krajowy porzadek prawny, „Państwo i Prawo”, nr 6.

Sobczyk (red.) (2015) Kodeks pracy. Komentarz, Warszawa.

Stanisz P. (2005) Wspólnotowy zakaz dyskryminacji, „Przegląd Sejmowy”, nr 1.

Stanisz P. (2006) Zakaz dyskryminacji ze względu na religię lub światopogląd w dyrektywie Rady Unii Europejskiej [w:] T. Guz, M. Kuć, (red.), Ius et fides. Księga jubileuszowa z okazji siedemdziesiątych urodzin Profesora Jana Świtki, Lublin.

Statut organisty w Archidiecezji Częstochowskiej (2009), https://archiczest.pl/dokumenty,18 (dostęp: 16.07.2016).

Strzała M. (2015), Gwarancje wolności religijnej w przepisach prawa pracy. Zarys prawnego de lege lata i postulaty de lege ferenda, „Internetowy Przegląd Prawniczy TBSP UJ”, nr 4.

Synod Archidiecezji Poznańskiej 2004-2008 (2008) Dokumenty, Poznań, nr 830.

Świątkowski A. (2016) Kodeks pracy. Komentarz, Warszawa.

Wagner B. (red.) (2004), Kodeks pracy. Komentarz, Gdańsk.

Wolnicki P., Kucharski O. (2018) Formy zatrudnienia i ich dokumentacja w kościołach i innych związkach wyznaniowych, Częstochowa.

Zieliński T.J. (2007) Pojęcie religii, wyznania, związku wyznaniowego i kościoła $w$ konstytucji Rzeczypospolitej Polskiej [w:] T.J.Zieliński (red.), Prawo i religia, t. 1, Warszawa.

Zieliński T.J. (2011) Prawo wewnętrzne gmin wyznaniowych żydowskich $w$ Polsce a normy ustawowe, „Studia z Prawa Wyznaniowego”, t. 14.

\section{Orzecznictwo}

Wyrok NSA z 23 stycznia 1998 r., I SA 1065/97, ONSA 1998, z. 4, poz. 135.

Wyrok ETPC z 15 stycznia 2013 r., Eweida i in. [Ladele] p. Wielka Brytania, LEX nr 1252935. Wyrok TSUE z 17 kwietnia 2018 r., Vera Egenberger p. Evangelisches Werk für Diakonie und Entwicklung eV, C-414/16, LEX nr 2476520. 